\title{
DIFFERENT RATES OF DEVELOPMENT ASSOCIATED WITH THE ALCOHOL DEHYDROGENASE LOCUS IN THE SEAWEED FLY, COELOPA FRIGIDA
}

\author{
T. H. DAY, T. DOBSON, P. C. HILLIER, D. T. PARKIN and BRYAN CLARKE \\ Department of Genetics, University of Nottingham, University Park, Nottingham NG7 2RD
}

Received 3.x.79

\section{SUMMARY}

The rate at which the seaweed fly, Coelopa frigida, develops from egg to adult is shown to be associated with the presence of alternate alleles at the alcohol dehydrogenase locus. Evidence for this correlation is presented for animals in laboratory culture and in natural populations. The relevance of the association to the maintenance of genetic polymorphism is discussed.

\section{INTRODUGTION}

THE seaweed fly, Coelopa frigida (Fab.), lives in piles of rotting seaweed, called wrack-beds, cast up on the shore by high tides. The biology of seaweed flies has been described by Egglishaw (1960) and Dobson (1974a, $b$, 1976). In every population so far studied in Britain $C$. frigida is polymorphic at the alcohol dehydrogenase locus $(A d h)$, with three alleles $\left(A d h^{B}\right.$, $A d h^{C}$ and $A d h^{D}$ ) segregating at frequencies greater than 5 per cent. In some populations two rare alleles $\left(A d h^{A}\right.$ and $\left.A d h^{E}\right)$ are also present. Geographical surveys (Kelsey, 1969; Clarke, Day, Dobson, Hillier and Parkinin preparation) carried out in England, Wales, Scotland and Denmark have shown limited (but significant) variation in gene frequencies at this locus. Whatever environmental differences there are between localities, they appear to have little perturbing influence upon the $A d h$ polymorphism. In this respect the polymorphism resembles the inversion polymorphism in Drosophila pseudoobscura, apparently being subject to what Dobzhansky (1962) has called " rigid" selection.

Observations while maintaining populations of seaweed flies in the laboratory, and during the course of breeding experiments, suggested that animals with different $A d h$ genotypes might develop at different rates. If this suggestion is correct, different development times could well be responsible for powerful selective forces acting upon the $A d h$ locus. Here we report experimental measurement of the times taken for animals of each genotype to develop from egg to adult. Differences between genotypes are large and clear. We have also enquired whether the differences found in laboratory cultures occur in natural populations.

\section{Materials and MEthods}

The animals were collected from a wild population at Westgate in Kent (Ordnance Survey grid reference: TR314703), and were maintained in the 
laboratory for several generations. The population size remained greater than 1000 animals. Three trays $(15 \times 8 \mathrm{~cm})$ were filled to a depth of $5 \mathrm{~cm}$ with a food consisting of 16.6 per cent (w/w) powdered seaweed ("Marinure", supplied by W. Smith (Horticultural) Ltd., Edgware, Middlesex), 3.32 per cent (w/w) cornmeal (Harrison Ltd., Radcliffe, Nottingham), 0.55 per cent (w/w) dried milk (Robinson's "High Protein Baby Food", Knights (Vestric) Ltd., Nottingham), and 0.62 per cent (w/w) New Zealand agar (Sigma Chemical Co., Poole, Dorset), made up in distilled water.

Several pieces of Laminaria stipe were placed on top of the medium to encourage egg-laying. The three trays were then placed in a glass aquarium tank $(60 \times 40 \times 30 \mathrm{~cm}) . \quad 50$ males and 50 females newly hatched from a laboratory population were placed in the tank. After 24 hours they were removed and the culture maintained at $27^{\circ} \mathrm{C}$ for the remainder of the experiment. The newly eclosed adult progeny were removed daily and stored at $-10^{\circ} \mathrm{C}$. The $A d h$ genotypes of half of each daily sample were determined using the method described by Day et al. (1974).

\section{Results}

The mean development times of each genotype are given in table 1 .

As commonly occurs in the Diptera, the males took significantly longer to develop than the females. In addition the males emerged over a longer period: the average times for the development of the fastest and slowest genotypes were 3.16 days apart in the males and only 2.46 days apart in the females. Eggs were laid over a period of one day, yet eclosion was spread over 12 days.

TABLE 1

Mean development times ( \pm standard errors) of each genotype in days

\begin{tabular}{|c|c|c|c|c|c|}
\hline \multirow[b]{2}{*}{ Genotype } & \multirow[b]{2}{*}{ Males } & \multirow[b]{2}{*}{ Females } & \multirow[b]{2}{*}{ Total } & \multicolumn{2}{|c|}{$\begin{array}{l}\text { Number of } \\
\text { animals }\end{array}$} \\
\hline & & & & Male & Female \\
\hline $\begin{array}{l}\mathrm{BB} \\
\mathrm{BC}\end{array}$ & $\begin{array}{l}20 \cdot 23 \pm 0 \cdot 33 \\
18 \cdot 89 \pm 0 \cdot 42\end{array}$ & $\begin{array}{l}17 \cdot 87 \pm 0 \cdot 49 \\
16 \cdot 75 \pm 0 \cdot 54\end{array}$ & $\begin{array}{l}19 \cdot 02 \pm 0.34 \\
17.52 \pm 0.43\end{array}$ & $\begin{array}{r}22 \\
9\end{array}$ & $\begin{array}{l}23 \\
16\end{array}$ \\
\hline $\mathrm{BD}$ & $19 \cdot 43 \pm 0 \cdot 16$ & $17 \cdot 61 \pm 0.19$ & $18 \cdot 37 \pm 0 \cdot 14$ & 129 & 179 \\
\hline $\mathrm{CD}$ & $17.56 \pm 0.61$ & $19.21 \pm 0.60$ & $18 \cdot 46 \pm 0.45$ & 16 & 19 \\
\hline DD & $17 \cdot 07 \pm 0.22$ & $17 \cdot 49 \pm 0 \cdot 22$ & $17 \cdot 27 \pm 0 \cdot 16$ & 151 & 139 \\
\hline Total & $18 \cdot 29 \pm 0 \cdot 14$ & $17 \cdot 63 \pm 0 \cdot 13$ & $17 \cdot 93 \pm 0.10$ & 327 & 376 \\
\hline
\end{tabular}

An analysis of variance revealed highly significant heterogeneity in the males between the development times of individual genotypes $\left(\mathrm{F}_{4,322}=23 \cdot 4\right.$, $\mathrm{p}<0.001)$. In the females the heterogeneity was also significant $\left(\mathrm{F}_{4,371}=\right.$ $2.41, \mathrm{p}=0.05$ ) but much less marked. The order of relative times is different in the two sexes.

\begin{tabular}{rcrrrr} 
& Fastest & & & & \\
\cline { 3 - 6 } Development order & 1 & 2 & 3 & 4 & Slowest \\
in males & DD & GD & BC & BD & BB \\
in females & BC & DD & BD & BB & CD
\end{tabular}

However, in both cases the three common genotypes $\mathrm{DD}, \mathrm{BD}$ and $\mathrm{BB}$ are in the same order; it is the rarer C-containing genotypes that differ in their 
relative positions. Excluding the $\mathrm{C}$ genotypes, the males retain a significant inter-genotypic heterogeneity $\left(\mathrm{F}_{2,299}=47.0, \mathrm{p}<0.001\right)$ but the females do $\operatorname{not}\left(\mathrm{F}_{2,338}=0.25, \mathrm{p}>0.2\right)$.

It is clear from fig. 1 that the genotype frequencies of the newly-emerging adults change with time, and that this change is very much more pronounced in males than females.

We have then, clear evidence that the $A d h$ locus is associated with differences in development time from egg to adult. This might be due to some overall difference in metabolic rate, so that all stages of the life cycle proceed at a changed rate, or there might be some critical stage (e.g., hatching, pupation, eclosion) through which the genotypes differentially proceed. We can crudely bisect the life cycle into pre- and post-pupation phases by studying the genotype frequencies in animals approaching the end of their larval development.

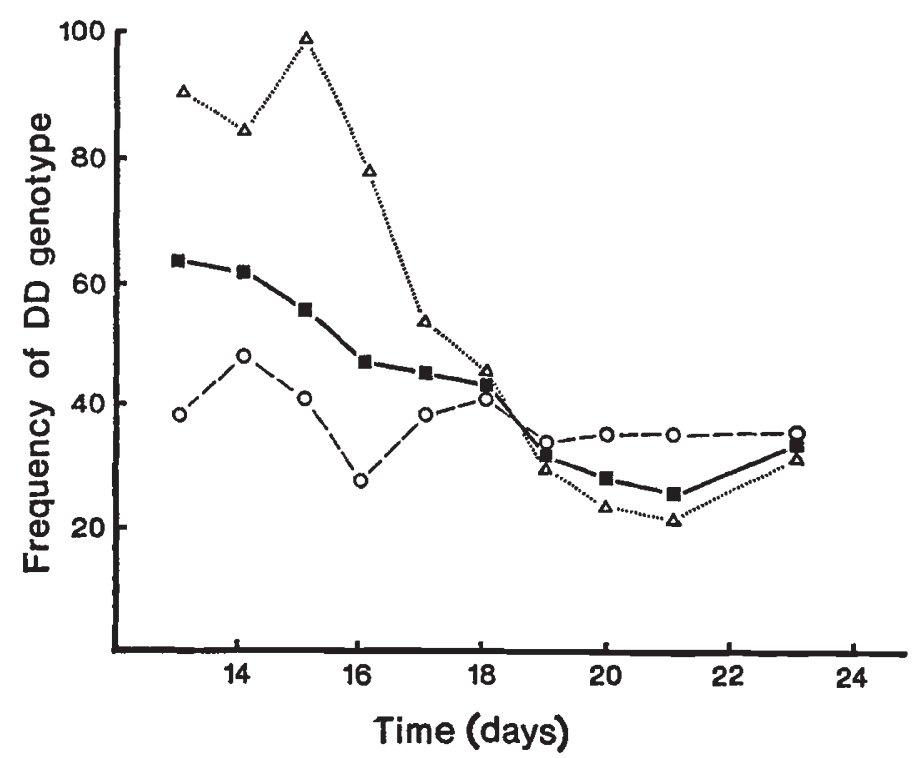

Frg. 1.-The frequency of DD homozygotes in newly eclosed adults. $\Delta=$ males; $O=$ females $\mathbf{\square}=$ combined males and females.

A synchronous laboratory population was established in the manner already described. A sample of 3rd instar larvae was taken 13 days after the parental flies had been removed, when pupation was just beginning. A second sample was taken seven days later, when pupation was well advanced and eclosion had just begun. The $A d h$ genotype of each larva was determined, and the results are given in table 2 . The samples were significantly different $\left(\chi_{5}^{2}=17.4, \mathrm{p}<0.01\right)$, and in the expected direction. The frequency of $\mathrm{DD}$ was lower in the later sample, and the frequencies of $\mathrm{BB}$ and $\mathrm{BD}$ higher. This is not only consistent with the differences described above, but indicates that the common genotypes take different times to pass through the larval stages. Experiments are in progress to partition the life cycle into shorter intervals. 
TABLE 2

Adh genotypes of larvae in a "young" and "old" laboratory population. The first sample was taken when pupation was just beginning (day 13) and the second when pupation was well advanced (day 20). Frequencies are showe in brackets

\begin{tabular}{lccccccc} 
& \multicolumn{9}{c}{ Genotypes } \\
& BB & BC & BD & CC & CD & DD & sample \\
" young " culture & 17 & 20 & 121 & 4 & 44 & 77 & 283 \\
(day 13) & $(0.06)$ & $(0 \cdot 07)$ & $(0 \cdot 43)$ & $(0 \cdot 01)$ & $(0 \cdot 16)$ & $(0 \cdot 27)$ & \\
" old " culture & 21 & 16 & 88 & 3 & 16 & 26 & 170 \\
(day 20) & $(0 \cdot 12)$ & $(0.09)$ & $(0.52)$ & $(0 \cdot 02)$ & $(0 \cdot 09)$ & $(0 \cdot 15)$ &
\end{tabular}

Heterogeneity between samples: $\chi_{(\mathrm{s})}^{2}=17 \cdot 4, \mathrm{p}<0 \cdot 01$

An important question is whether these differences also occur in wild populations growing on their natural food--decomposing brown algae of the genus Laminaria. In order to answer this question five distantly separated populations were studied. Samples of larvae were collected from each locality together with the decaying seaweed in which they were living. These were reared until eclosion, and then samples of adults collected over a number of days. The genotype frequencies of adults eclosing early in the sequence of samples were compared with the frequencies of those eclosing relatively late. If the developmental differences were present in the natural populations, we would expect the frequency of DD homozygotes to decrease, and the frequencies of BB's and BD's to increase, in the later batches.

These predictions are confirmed by the results, which are summarised diagrammatically in table 3 . A " + " sign shows that the frequency increased with time, i.e., it was higher in the last batch than in the first, and a " - " sign shows that it decreased. The " = " sign indicates that there was no evident change in genotype frequency.

In every case the frequency of DD decreases, and the frequency of BB

TABLE 3

Changes in genotype frequencies of the early and late eclosing adults from samples of natural populations. $A$ " + " sign signifies an increase in frequency between the early and late adults; a " - " sign signifies a decrease; " =" indicates no change. Ordnance Survey grid references are given for each location

\begin{tabular}{|c|c|c|c|c|c|}
\hline Location of population & $\mathrm{BB}$ & $\mathrm{BC}$ & $\mathrm{BD}$ & $\mathrm{CC}$ & $\mathrm{CD}$ \\
\hline $\begin{array}{l}\text { Westgate } \\
\text { (east of London) } \\
\text { TR314703 }\end{array}$ & + & - & + & + & + \\
\hline $\begin{array}{l}\text { Dawlish } \\
\text { (south of Exeter) } \\
\text { SX963762 }\end{array}$ & + & + & + & $=$ & - \\
\hline $\begin{array}{l}\text { St. Mary's Island } \\
\text { (north of Newcastle) } \\
\text { NZ351753 }\end{array}$ & + & + & + & - & + \\
\hline $\begin{array}{l}\text { Sambo's Grave } \\
\text { (north of Blackpool) } \\
\text { SD422556 }\end{array}$ & + & - & $=$ & + & + \\
\hline $\begin{array}{l}\text { Aberporth } \\
\text { (south of Aberystwyth) } \\
\text { SN262517 }\end{array}$ & + & $=$ & - & $=$ & - \\
\hline
\end{tabular}


increases. In most of them the frequency of BD also increases. The Cbearing genotypes show the variable results that would be predicted from their behaviour in the laboratory populations. Thus it seems that the association between the $A d h$ locus and the rate of development exists not only in laboratory cultures but also in natural populations.

\section{Discussion}

Coelop a frigida breeds only in wrack-beds, which are usually stable for the 28 days period between lunar high tides. Despite this 28-day regularity in the deposition and removal of wrack-beds, there is considerable variation depending upon winds, storms and other irregular factors. Dobson (1973, $1974 a, b$ ) observed that some wrack-beds lasted only a few hours or days, while others were stable for $10-12$ weeks. A common variant is the twoweek cycle in which the bed is removed by the inter-spring high tide. He also noticed times when there was no wrack-bed present at all. In view of the association between rate of development and $A d h$ genotype, we would expect the frequencies at this locus to be altered by such irregularity in food supply.

The removal of wrack-beds before eclosion is complete should cause the loss of more individuals carrying the $\mathrm{B}$ allele than those carrying the $\mathrm{D}$ allele. The earlier the loss occurs, the greater should be the selection against the B allele. It is more difficult to predict the genetic consequences of a prolonged persistence of the wrack-bed, or of gaps between successive wrack-bed cycles. Not only might the exact timing be important, but also such biological variables as the tolerance of animals to old food, or to no food at all, the longevity of adults and the maintenance of fertility in ageing flies. If there is no association between such variables and the $A d h$ locus, we might expect extended cycles to favour the slower-developing B-carrying individuals. We are currently studying the effects that different lengths of cycle have upon the genotype frequencies at the $A d h$ locus.

Whatever the outcome, we would certainly expect irregularities in cycle times to have a perturbing effect on genotype frequencies; yet samples taken in different parts of Britain at different times of the year all fall within a narrow range of variation. There are a number of possible explanations for this contradiction. One is that the adults are so long-lived that differences in egg-to-adult development times are rendered inconsequential. Another is that migration is large enough to have the same effect, although adjacent populations should be subject to the same climatic irregularities. Yet another possibility is that the polymorphism is subject to counter-acting selective forces of a stabilising kind that completely outweigh the selection due to differential development times. Preliminary results (Collins, 1978; Day, unpublished) suggest that this may be so.

We must stress that although there is an association between rate of development and $A d h$ genotype, the control of development need not involve the product of the $A d h$ locus. There is no immediately obvious explanation for such an involvement. The connection may be indirect, caused by linkage disequilibrium between $A d h$ and one or more other loci involved in the control of development. One of the chromosomal inversion polymorphisms reported by Philip (1958) may be involved. Preliminary evidence suggests that there is indeed a non-random association between the 
Adh locus and an inversion on chromosome 1. However, the directness or indirectness of the connection between $A d h$ and rate of development in no way alters its possible selective consequences. The different rates of development of animals carrying alternate $A d h$ genotypes may still result in strong selective forces, and the absence of any large differences in gene frequencies between British populations remains a puzzle.

Acknowledgments.-This work was supported by a grant (to B.C.) from the Nuffield Foundation, whose help is gratefully acknowledged.

\section{REFERENCES}

collins, P. M. 1978. Studies on genetic polymorphism in Coelopa frigida. Ph.D. Thesis. University of Nottingham.

DAY, T. H., HILlIER, P. C., AND CLARKE, B. 1974. Properties of genetically polymorphic isozymes of alcohol dehydrogenase in Drosophila melanogaster. Biochem. Genet. 11, 141153.

DoBson, T. 1973. Coelopa frigida (Fabricius) and Coelopa pilipes (Halliday) (Diptera, Coelopidae): a study of two sympatric species. M.Sc. Thesis, University of Newcastle-uponTyne.

Dobson, т. 1974a. Studies on the biology of the kelp fly Coelopa in Great Britain. $\mathcal{F}$. Nat. Hist. 8, 155-177.

DOBson, T. 1974b. Mechanisms controlling species composition in natural populations of the seaweed-fly Coelopa. F. Nat. Hist. 8, 653-673.

Dobson, т. 1976. Seaweed flies (Diptera: Coelopidae, etc.). In: Marine Insects, ed. L. Cheng, North-Holland Publishing Company.

Dobzhansky, т. 1962. Rigid vs. flexible chromosomal polymorphism in Drosophila. Am. Naturalist 96, 321-328.

Egglishaw, H. J. 1960. Studies on the family Coelopidae (Diptera). Trans. R. ent. Soc. Lond. 112, 109-140.

KELSEY, M. C. 1969. An investigation of the alcohol dehydrogenase polymorphism in Coelopa frigida (Fab). B.Sc. Thesis, University of Edinburgh.

PHILIP, U. 1958. Genetics and cytology of the seaweed fly Coelopa frigida (Fab). Proc. Xih Congr. Genet., Montreal, p. 217. 